\author{
Jacek Napieraea
}

\title{
A few remarks on the interpretation of European company law ${ }^{1}$
}

\section{The position of European company law in the Polish legal system}

European company law belongs to company law systems in each Member State, Poland included. The influence of European company law on Polish company law commenced as soon as the Europe Agreement entered into force. ${ }^{2}$ Thereafter, under Article 2 of the Act concerning the conditions of accession of the Republic of Poland to the European Union, ${ }^{3}$ constituting an integral part of the Accession Treaty of $2003^{4}$ [Article 1(2)], European company law officially became part of the Polish company law regime. Therefore, European company law did not convert into national law, but - remaining distinct and autonomous - merged into it and became part of it. ${ }^{5}$ Consequently, domestic company law remains in force in each Member State, accompanied by l'acquis communautaire pertaining to companies, ${ }^{6}$ leaving the courts no choice but to apply not only Polish but also European company law.

1 This article - financed the National Science Centre, Poland (Project no. 2015/19/B/HS5/00002) - is an English translation by Agata Iżyk of the author's article published in Polish in: Usus Magister Est Optimus. Rozprawy prawnicze ofiarowane Profesorowi Andrzejowi Kubasowi, eds. B. Jelonek-Jarco, R. Kos, J. Zawadzka, Warszawa 2016.

2 The Europe Agreement establishing an association between the European Communities and their Member States on the one part, and the Republic of Poland on the other part, was drafted in Brussels on 16 December 1991 (Dz.U. 1994 no. 11 item 38, as amended).

3 EU OJ L 236 (2003), p. 33.

4 Ibidem, p. 17.

5 C. Mik, Metodologia implementacji europejskiego prawa wspólnotowego w krajowych porzadkach prawnych, [in:] Implementacja prawa integracji europejskiej w krajowych porzadkach prawnych, ed. C. Mik, Toruń 1998, p. 21.

6 E. Eętowska, „Multicentrycznośc” polskiego systemu prawa i wyktadnia jej przyjazna, [in:] Rozprawy prawnicze. Ksiega pamiątkowa Profesora Maksymiliana Pazdana, eds. L. Ogiegło, W. Popiołek, M. Szpunar, Kraków 2002, p. 1127. 
The process of applying company law entails that a competent body (a court of law) makes decisions, formulating an individual and concrete rule of conduct based on the general and abstracts rules of law in force. To accomplish this, the rules of law must first be decoded from legal texts by way of interpretation. ${ }^{7}$ Decoding a rule of law in force involves determining its syntactic and semantic elements distributed in legal acts, by institutionally independent legislators by means of rules of interpretation. In real-life situations, a rule of law may be decoded from either a piece of European law (whether primary and secondary) or domestic law. The decision of the court of law may also be based on rules of law which, although not expressly presented in a legal act, remain in force due to their being drawn through logical deduction based on the rules of inference (i.e. legal reasoning: logical and instrumental deduction of a rule from a rule, as well as deduction based on the interpretative arguments of legal analogy and argumentum a fortiori, based on the premise that the institutional lawmaker is consistent as regards their axiological evaluations). ${ }^{8}$

When in doubt over the interpretation of the wording of European acts of law, a national court may (and - should its ruling be final and absolute - must) apply to the Court of Justice of the European Union (the "Court") for a judgment to be delivered under the preliminary ruling procedure. However, should no doubt arise, a national court (the court of the last instance) may construe the law itself, having regard to the assumptions of the acte clair doctrine; questions referred for preliminary rulings may also pertain to doubts over the understanding of the acte clair doctrine per se. ${ }^{9}$

The Court does not apply European company law, nor does it apply or interpret the domestic company legislation of a given Member State. What the Court does is interpret European company law in the course of a preliminary ruling procedure instigated by domestic courts referring questions for preliminary rulings pursuant to Article 267 of the Treaty on the Functioning of the European Union (the TFEU), and determine

7 Z. Radwański, M. Zieliński, Stosowanie i wyktadnia prawa cywilnego, [in:] System prawa prywatnego, vol. 1, Prawo cywilne - część ogólna, ed. M. Safjan, Warszawa 2012, pp. 482-483, § 54.

8 Z. Ziembiński, Teoria prawa, Warszawa - Poznań 1978, pp. 125-129; more on the subject cf.

A. Godek, Zastosowanie derywacyjnej koncepcji wyktadni prawa do rozstrzygania spraw ze stosowaniem przepisów unijnych, „Ruch Prawniczy Ekonomiczny i Socjologiczny” 2011, vol. 1, pp. 21-39.

9 Cf. $\S \S 60-69$ of the opinion of Advocate General Wahl of 13 May 2015 to the joint cases C-72/14 and C-197/14, X and T.A. van Dijk. According to the Court: "the third paragraph of Article 267 TFEU must be interpreted as meaning that a national court or tribunal against whose decisions there is no judicial remedy under national law, such as the referring court, is not required to make a reference to the Court of Justice of the European Union on the sole ground that a lower national court, in a case similar to the one before it and involving the same legal issue, has referred a question to the Court for a preliminary ruling; nor is it required to wait until an answer to that question has been given" (C-72/14 and C-197/14, X and T.A. van Dijk, § 2. All judgments of the European Court of Justice were accessed via: http://curia.europa.eu). 
a Member State's failure to fulfil its obligations under the treaties pursuant to Article 258 TFEU. The interpretation of European company law also accompanies hearing and determining complaints for the annulment of a European act of law (Article 363 TFEU).

The process of interpreting European company law is influenced by both the nature of European company legislation and the nature of European law per se.

\section{Distinctive features of European company law}

European company law is specific in its character, which is reflected in: (a) the role it plays in the EU internal market, (b) the means and manner of regulation, and (c) the nature of the subject matter contemplated in acts of law.

\section{European company law as one of the components of the internal market}

European company law is a key element of the EU internal market. ${ }^{10}$ Companies enjoy cross-border mobility as part of the freedom of establishment stipulated in Article 49 TFEU.The internal market provides the freedom of movement of goods, people, services and capital under Article 26(2) TFEU. The fundamental freedoms percolate one another and, consequently, the Court's interpretation of one freedom affects (the understanding of) the subject matter of the remaining ones. The general principles put forward by the Court whilst construing the freedom of movement of goods greatly influence the interpretation of the rules of law pertaining to the freedom of establishment. Let me quote an example of the principle according to which the law takes into account the personal statute of a company in line with the law of the state where it has been incorporated. The origins of this rule may be traced back to the interpretation of the laws on the freedom of movement of goods. In the landmark Cassis de Dijon case ${ }^{11}$ the Court held that a Member State may not restrict the access of goods produced in another Member State to its territory exclusively on the grounds that such goods fail to conform to the conditions set out in the laws and regulations of such a Member State. ${ }^{12}$ The principle of respecting the personal statute of a cross-border company - in a state to which it has transferred its

10 Action Plan: European company law and corporate governance - a modern legal framework for more engaged shareholders and sustainable companies, Strasbourg, 12.12.2012, $\operatorname{COM}(2012)$ 740, p. 4; K.J. Hopt, The European Company Law Action Plan Revisited: An Introduction, [in:] K. Geens, K.J. Hopt, The European Company Law Action Plan Revisited, Leuven 2010, p. 18: Corporate mobility is the very essence of the internal market. We should do everything to promote it for the sake of entrepreneurial freedom as well as for the healthy effect of competition.

11 120/78, Cassis de Dijon.

12 A. Wróbel, Znaczenie orzecznictwa "Cassis de Dijon" Trybunatu Sprawiedliwości Wspólnot Europejskich a rozwój europejskiego prawa żywnościowego, "Rejent"1995, no. 10, p. 29. 
seat pursuant to the freedom of establishment - was expressly put into words later in the widely quoted Überseering case (C-208/00). ${ }^{13}$

More to the point, the rule put forward in the joint case of Keck-Mithouard ${ }^{14}$ may be adapted so as to allow the assertion that the freedom of establishment may be restricted only by such measures (rules) which regulate the access to a foreign market, and not those regulating the functioning of companies on such a market. Rules aimed at hindering foreign companies' access to the market may be enacted as long as their application is reasonably justified. On the other hand, rules aimed at hindering a foreign company's functioning on the market - typically - fall within the blanket ban on discriminatory treatment. Rules of law are deemed not to be in breach of the freedom of establishment so long as they apply to all market participants on such a market (in other words, both foreign and domestic companies) and do not impede foreign companies' access to the market any more than they do as regards domestic companies. ${ }^{15}$ The Court expressly referred to the Keck-Mithouard rule in the Commission v. Portugal case (C-171/08). According to the Court, privileged shares "affect the position of a person acquiring a shareholding as such and are thus liable to deter investors from other Member States from making such investments and, consequently, affect access to the market."16

\section{Manner of regulation of European company law}

In consequence, European company law has reached an unprecedented degree of harmonisation of domestic company law regulations when compared to other branches of private law. ${ }^{17}$ Yet European company law is far from being comprehensive, on the contrary, it coordinates selected aspects of company law ${ }^{18}$ and only to a necessary degree [Article 50(2)(g) TFEU]. This selective method of regulation, i.e. a more detailed regulation of individual branches of company law, e.g. the projected regulations of holding companies, is envisaged as enabling law implemented by a European model of a group

13 C-208/00, Überseering.

14 C-267/91 and C-268/91, Keck and Mithouard.

15 K. Steinke, Die Übertragbarkeit der Keck-Rechtsprechung des EuGH auf die Niederlassungsfreiheit, Frankfurt am Main - Berlin - Bern - Bruxelles - New York - Oxford - Wien 2009, p. 251.

16 C-171/08, European Commission v. Portuguese Republic, § 67, C-212/09; European Commission v. Portuguese Republic, § 64, C-565/08; European Commission v. Italian Republic, § 67; cf. also C-594/14, Simona Kornhaas v. Thomas Dithmar, § 28.

17 M. Lutter, W. Bayer, J. Schmidt, Europäisches Unternehmensrechts- und Kapitalmarktrecht, "Zeitschrift für Unternehmens- und Gesellschaftsrecht", 2012, no. 1, p. 3, § 2; K.J. Hopt, Europäisches Gesellschaftsrecht im Lichte des Aktionsplans der Europäischen Kommission vom Dezember 2012, "Zeitschrift für Unternehmens- und Gesellschaftsrecht" 2013, no. 2, pp. 167-168.

18 Opinion of Advocate General Trstenjak of 2 June 2010 to the case C-81/09, Idrima Tipou AE v. Ipourgos Tipou kai Meson Mazikis Enimerosis, § 25; A. Opalski, Europejskie prawo spótek zasady prawa europejskiego i ich wplyw na polskie prawo spótek, Warszawa 2010, p. 65. 
interest. ${ }^{19}$ Given that harmonization by way of directives applies only to selected company law institutions, there is no doubt that in other matters Member States may shape their respective company law regimes freely, however, having regard for the fact that such legislation must not restrict the fundamental freedoms guaranteed under the Treaties. ${ }^{20}$

The process of applying European company law is largely contingent on the effect of the determination whether a given company law institution has been regulated by the European legislator or - on the contrary - has been left to the discretion of the Member States; e.g. in the Impaco Azul Lda case, the Court points out that Member States are given autonomy as regards restricting the limitation of a member's liability for the debts of a company. ${ }^{21}$ This point corresponds to the Idryma Typou AE case, where the Court also ruled on a Member State's autonomy, as regards restricting the limitation of a company's liability to the value of its assets. ${ }^{22}$

Autonomous regulation at the European level adjoins autonomous legislation in domestic jurisdictions, which is reflected in the interpretation of the subjective scope of the freedom of establishment in the Daily Mail case ${ }^{23}$, further developed in the Cartesio case $^{24}$ and confirmed in the National Grid Indus ${ }^{25}$ and Vale ${ }^{26}$ cases. In the opinion of the Court, whether a company may rely on the prohibition on restrictions of the freedom of establishment (i.e. it is the addressee of Article 49 TFEU) depends greatly on whether such a company falls within the scope of Article 54 TFEU under domestic law.

\section{The distinctive nature of the subject matter of European company law}

Experts in the field emphasise the fact that "to characterise the process of interpretation of civil law (its provisions), it is paramount to have regard to the distinctive features of civil law first," ${ }^{27}$ including in particular the fact that it regulates legal relations between autonomous actors. Under company legislation, classified as private (civil) law, autono-

19 Taking the initiative on the issue has been announced in item 4.6. of the Action Plan COM(2012) 740, pp. 16-17. Cf. Response to the European Commission's Action Plan on Company Law and Corporate Governance by the former Reflection Group on the Future of UE Company Law, "European Company and Financial Law Review" 2013, no. 3, pp. 325-326; P.-H. Conac, Director's Duties in Groups of Companies - Legalizing the Interest of the Group at the European Level, "European Company and Financial Law Review" 2013, no. 2, pp. 194-226. Cf. Forum Europaeum on Company Groups, Eckpunkte für einen Rechtsrahmen zur erleichterten Führung von grenzüberschreitenden Unternehmensgruppen in Europa, "Zeitschrift für Unternehmens- und Gesellschaftsrecht" 2015, no. 4, pp. 505-515.

20 Cf. § 31 of C-347/09, J. Dickinger, F. Ömer.

21 C-186/12, Impaco Azul Lda, § 35 ab initio.

22 C-81/09, Idryma Typou AE, $\S 40$ and $\S 44$.

23 81/87, Daily Mail.

24 C-210/06, Cartesio.

25 C-371/10, National Grid Indus.

26 C-378/10, Vale.

27 Z. Radwański, M. Zieliński, op. cit., p. 478, § 51. 
mous entities take various roles (e.g. individuals and bodies corporate as shareholders or members of multi-member governing bodies of a company), which in turn affects, for example, the justification for qualifying the regulation of the relationship between a company's governing bodies as acts-in-law. ${ }^{28}$ The interpretation of company legislation greatly depends on whether the act of law under scrutiny regulates internal or external relations pertaining to companies. On the one hand, application of general principles of civil law, which concern external relations, i.e. relations between separate and unrelated entities, to internal relations between governing bodies of same company should be done with caution. ${ }^{29}$ On the other, the general objective of regulations pertaining to both spheres are indeed different, which is reflected in the Court's purposive interpretation of European company law, e.g. in the Commission v. Spain case, ${ }^{30}$ where the Court held that Spanish company law provisions contravene the second company law directive (77/91/EC), to the extent in which they equal the pre-emptive right attached to shares (and pertaining to internal relations within a company) with the right vested in the holder of convertible (hybrid) debentures (and pertaining to external relations between a company and its stakeholders). By the same token, in the Alfred Hirmann case pursuant to a reference for preliminary ruling, the Court answered the following question: do the provisions of the second directive aimed at maintaining (and thus protecting) share capital preclude the situation where a company is obliged to reimburse the purchase price for shares to a shareholder as a consequence of a share purchase agreement having been rescinded? The Court provided a negative answer. Firstly, the second directive regulates the internal relations between shareholders and a company under its articles of association pertaining to the internal relations within a company exclusively, hence it fails to touch on the issue of liability for a breach of a share purchase agreement. Any compensation extended by a company for a breach of its disclosure obligations does not fall within the meaning of the word "distribution" as provided in Article 15 of the second directive. ${ }^{31}$ And secondly, a shareholder in entitled to return their shares to a company, should such shares have been purchased as a result of a misrepresentation on the part of the company, and such entitlement does not fall within the buy-back ban set out in Article 18 of the directive. ${ }^{32}$

The clear distinction between the company's internal and external relations finds its merits also in matters concerning jurisdiction. In the opinion of the Court, the domestic court in a Member State where insolvency proceedings have been instigated enjoys

28 I.e. not the relation between governing bodies, but "the relation between a body which adopts a resolution and the persons appointed to another governing body (the management board)". Cf. Z. Radwański, [in:] System prawa prywatnego, vol. 2, op. cit., p. 181, § 38.

29 I CSK 11/07, [in:] OSNC 2008, no. 5, item 51.

30 C-338/06, Commission of the European Communities v. Kingdom of Spain, §§ 50-57.

$31 \mathrm{C}-174 / 12$, Alfred Hirmann, $\S$ 27-32.

32 C-174/12, Alfred Hirmann, § 34. 
jurisdiction to hear and determine an action brought by the liquidator in insolvency proceedings against the managing director of the debtor for reimbursement of payments which were made after the company became insolvent, or after it had been established that the company's liabilities exceeded its assets. ${ }^{33}$ The external relations, on the other hand, are contemplated in cases pertaining to the liability of either members of a company's governing bodies or its shareholders towards a company's creditors. To quote one example, in the view of the Court, the court having jurisdiction to hear actions seeking to hold liable a member of the board of directors and a shareholder of a limited company for the debts of that company, due to the fact that they have allowed the company to continue in existence despite the fact that it had been underfinanced and thus should have been would-up, is the same as the court having jurisdiction over the place where the harmful event occurred or could have occurred occur. ${ }^{34}$

\section{The distinctive nature of European company law}

L'acquis communautaire is separate from both international law and the internal law of Member States. ${ }^{35}$ The distinctive nature of (European) company law is reflected in its (a) autonomy, (b) applied methods of interpretation, and (c) significance for pro-European interpretation of domestic company legislation.

\section{Autonomy}

Institutions and terminology under EU company legislation are, in principle, autonomous, i.e. the manner in which they are interpreted should be grounded on EU legislation exclusively, unless a given piece of legislation contains express references to domestic legislation for determining the meaning and scope of a contemplated term.

The Court has consistently held that it follows from the need for uniform application of European Union law and from the principle of equality that the terms of a provision of that law which makes no express reference to the law of the Member States for the purpose of determining its meaning and scope must normally be given an autonomous and uniform interpretation throughout the Union, having regard to the context of the provision and the objective pursued by the legislation in question. ${ }^{36}$

33 C-295/13, H., § 1.

34 C-147/12, ÖFAB, Östergötlands Fastigheter AB, § 55(i).

35 M. Safjan, Europeizacja prawa prywatnego - erwolucja czy rewolucja. Perspektywa orzecznicza, [in:] Aurea praxis aurea theoria. Ksiega pamiatkowa ku czci Profesora Tadeusza Erecińskiego, eds. J. Gudowski, K. Weitz, vol. 2, Warszawa 2011, p. 2514.

36 C-396/09, Interedil Srl, in liquidation, § 42. 


\section{Methods of interpretation}

The Court resigned from formulating its own methods of interpretation; instead it uses the familiar, traditional methods of textual, systemic, functional, historic and comparative interpretation. The methods are subject to the principle of uniform interpretation, aimed at ensuring that l'acquis communautaire is uniformly construed, interpreted and applied EU-wide. ${ }^{37}$

The Court interprets the law with regard to its regulatory context and the aim to which the legislator aspired (thus the significance of the functional approach to interpretation), ${ }^{38}$ contemporaneously taking into consideration all methods of interpretation, i.e. the Court does not rest upon having linguistically construed a rule from an explicit and unambiguous piece of legislation. ${ }^{39}$ In line with the so-called theory of derivative interpretation (the derivative concept of legal interpretation), the process of construing a law commences with linguistic interpretation, the results of which must be further verified by way of external rules (systemic and functional interpretation). ${ }^{40}$

To quote one example: in the judgment in re Michael Timmel the Court construed Article 14(2)(b) of the prospectus directive ${ }^{41}$ with a view to determining whether a prospectus must be made available at both the issuer and the intermediary's offices. The dilemmas pertaining to the interpretation of this article arose as a consequence of discrepancies between the language version of the directive.

\footnotetext{
The referring court points out that according to the German version of that provision the base prospectus must be made available to the public at the registered office of the issuer or at the offices of the financial intermediary, whereas according to the versions of the provision in Spanish, English and French that prospectus must be available in both places. ${ }^{42}$
}

37 C. Mik, Europejskie prawo wspólnotowe, Warszawa 2000, p. 685, § 1673.

38 The opinion of the Advocate General Verica Trstenjak of 2 June 2010 to the case C-81/09, Idryma Typou $\mathrm{A} E$ and case law quoted in annotation 23 thereto.

39 J. Wróblewski, Rozumienie prawa i jego wykładnia, Wrocław 1990, pp. 76-88; Z. Radwański, Derywacyjna koncepcja wyktadni polskiego prawa prywatnego a wyktadnia prawa Unii Europejskiej, [in:] Aurea praxis..., op. cit., p. 2508 et seq.

40 Z. Radwański, Uwagi o wyktadni prawa cywilnego, „Ruch Prawniczy Ekonomiczny i Socjologiczny" 2009, no. 1, p. 12; A. Wentkowska, Interpretacja in dubio pro communitate - dyrektywa wyktadni proeuropejskiej w orzecznictwie sadów polskich, [in:] Doświadczenia prawne pierwszych lat cztonkostwa Polski w Unii Europejskiej, eds. S. Biernat, S. Dudzik, Warszawa 2011, p. 148.

41 Directive 2003/71/EC of the European Parliament and of the Council of 4 November 2003 on the prospectus to be published when securities are offered to the public or admitted to trading and amending Directive 2001/34/EC, EU OJ L 345,31/12/2003 P. 0064.

42 C-359/12, Michael Timmel, § 61. 
The Court indicated that "in this regard, it is to be recalled that a text which, by reason of divergences between the various language versions, does not lend itself to a clear and uniform interpretation must be interpreted by reference to both the purpose and the general scheme" of 2003/71/EC directive. ${ }^{43} \S \S 4$ and 10 of the recitals of the directive clearly state that the directive aims to ensure investor protection and the widest possible access for undertakings to investment capital EU-wide:

[...] those objectives could be undermined in the situation where the issuer's office is in a different Member State from that of the financial intermediary, since a prospectus made available to the public only in paper form would then be available only at one of those two offices. ${ }^{44}$

Such a result of interpretation is reinforced by the general structure of the directive.

Since Article 14(7) of the Prospectus Directive requires that, where the prospectus is made available by publication in electronic form, a paper copy be delivered to the investor, upon his request, by the issuer or the financial intermediaries, it is necessary for the financial intermediaries to have a copy of the prospectus in order to be able to perform that obligation. ${ }^{45}$

Ergo, Article 14(2)(b) of the prospectus directive should be construed and interpreted in such a way as to allow the interpreter to conclude that a prospectus be made available in the office of the issuer and the financial intermediary both. ${ }^{46}$

\section{Inference of legal rules}

Decoding a company law rule in force does not cease at reading it according to the rules of language. In force are also rules deducted from rules, in line with the rules of logical inference. The Court referred to reasoning based on legal inference as well as logical reasoning based on the premise that the lawmaker is consistent in their axiological evaluations (a fortiori, per analogiam reasoning) whilst interpreting the subject matter of the freedom of establishment. For instance, in its judgment in re Jochen Dickinger, Franz Ömer the Court based its a maiori ad minus reasoning on a rule encoded in Article 49 of TEEC, subject to its interpretation in one of its previous cases. The said rule applies to an operator offering betting and gaming services in another Member State provided

43 Ibidem, $§ 62$.

44 Ibidem, $\$ 65$.

45 Ibidem, $\$ 67$ ab initio.

$46 \mathrm{Ibidem}, \S 4$ of the judgment. Therefore, it must be pointed out that Polish wording of Article $14(2)(b)$ contains an alternative ,and/or" not cumulative "and." 
that it uses intermediaries having offices in the same Member States as its clients. ${ }^{47}$ In the opinion of the Court "that article applies a fortiori where the operator of games of chance makes use not of intermediaries but of a mere provider of computer support services in the host Member State." ${ }^{48}$

On a different occasion, in the judgment in re Commission of the European Communities v. Federal Republic of Germany the Court used a simili reasoning on the grounds of a rule of law it read in one of its previous judgments, in light of which "it would be incompatible with the right of freedom of movement were a citizen of the European Union, in the Member State of which he is a national, to receive treatment less favourable than that which he would enjoy had he not availed himself of the freedoms offered by the Treaty in relation to movement." ${ }^{49}$ The Court believes that such reasoning applies per analogiam to persons, who exercise their fundamental freedom of establishment:

In so far as the effect of the transitional provisions is that psychotherapists established in Germany who established themselves outside that Member State during the reference period and then returned to Germany before 1 January 1999 are less favourably treated than psychotherapists who remained in Germany during the same period, those provisions are incompatible with the provisions of the Treaty concerning freedom of establishment, unless they can be justified..$^{50}$

\section{Direct and indirect application of European company law}

The rules of European company law - though autonomous - are becoming part of domestic legislation (pertaining to company law). The effectiveness of l'acquis requires that the rulings be twofold:

Firstly, a prospective conflict between domestic and European rules should be settled with regard to the principle of the priority of European law. This principle has been worked out in the Court's case law (see Costa/E.N.E.L, 6-64), although - as emphasized by the (Polish) Constitutional Court - it transpires "indirectly from a number of provisions of the Treaties, including but not limited to, those determining the obliga-

47 C-243/01, Piergiorgio Gambelli and Others, $§ 58$.

48 C-347/09, Jochen Dickinger, Franz Ömer, § 37 in fine, cf. also C-470/13, Generali-Providencia Biztosító Zrt v. Közbeszerzési Hatóság Közbeszerzési Döntőbizottság, § 36. According to the Court's judgment, Articles 49 and 56 of TFEU do not contravene with application of domestic provisions enabling contracting authorities to exclude economic operators, inter alia, for serious professional misconduct, such as infringement of antitrust rules, as such misconduct may render an economic operator's integrity questionable.

49 C-456/05, Commission of the European Communities v. Federal Republic of Germany, § 58. 50 Ibidem, 559 . 
tions of Member States as regards enforcement of European legislation." ${ }^{51}$ From the perspective of legal practitioners applying the law, the principle is given the weight of a rule of systemic interpretation.

Secondly, where European law cannot be applied directly, the gap is filled with a domestic rule of law, construed with regard to the contents and the objective of a directive. In such cases, the rulings returned by courts rely on domestic legislation, whereas European company law serves as a point of reference..$^{52}$ The obligation to construe the law having regard to European legislation transpires from both Article 4(3)(2) of the Treaty on the European Union obliging Member States to undertake all measures, and the Constitution of the Republic of Poland..$^{53}$ The emphasis on the "indirect" application of European company law allows the conclusion to be drawn that "the obligation to interpret company law provisions in line with European company law entails in fact the priority rule, hence, it is justified that it be qualified as systematic rule of interpretation." ${ }^{54}$ However, it must be realised that direct application of European law and pro-EU interpretation of domestic law are categorically different phenomena. While applying the priority principle a court applies a rule of European law, whereas pro-EU interpretation is applied in the course of construing domestic laws.

Bearing in mind the principle of the priority of European law, a national court hearing a given case applies the rule expressed in EU legislation. On the other hand, construing a piece of legislation in line with the pro-European interpretation of company law, the court interprets the national law as far as possible with the purpose and the wording of the directive serving as a point of reference, ${ }^{55}$ having regard to all domestic methods of interpretation, bearing in mind the ban on contra legem interpretation.. Implementing the proposition of pro-European interpretation of law entails either accepting this result of domestic interpretation, which is the closest to the purposes of the directive (in the light of the secondary preferential rule of interpretation), or - should the purpose of a given piece of domestic legislation not be expressly exhibited by the national legislator - having regard to the purpose of the directive whilst determining the meaning and sense of the wording within a given functional context. ${ }^{56}$

51 Item III.2.2 of obiter dicta to the judgment of Poland's Constitutional Court in re SK 45/09, OTK-A 2011, no. 9, item 97.

52 A. Kalisz, Wyktadnia i stosowanie prawa wspólnotowego, Warszawa 2007, p. 49.

53 The judgment of Poland's Constitutional Court in re K 2/02, OTK-A 2003, no. 1, item 4, pp. 59, 68.

54 Z. Radwański, M. Zieliński, op. cit., p. 537, § 184.

55 C-106/89, Marleasing.

56 U. Babusaux, Die richtlinienkonforme Auslegung im deutschen und französischen Zivilrecht. Ein rechtsvergleichender Beitrag zur europäischen Methodendiskussion, Baden-Baden 2007, p. 41; J. Napierała, Uwagi na temat wyktadni prawa krajowego zgodnej z dyrektywami europejskiego prawa spótek, „Czasopismo Kwartalne Całego Prawa Handlowego, Upadłościowego oraz Rynku Ka- 


\section{Conclusion}

In order to hear and determine a given case pertaining to company law, the national court must often untie the knotty dilemma of interpreting EU company law, which may occur in two situations: (a) either when the national court applies EU provisions directly (e.g. applying the regulation pertaining to the European company or directly effective provisions of company law directives, or when such provisions must be directly applied in lieu of domestic provisions in line with the principle of priority of EU law), or (b) when the national court desires to interpret domestic company law provisions in a pro-European manner, which in turn requires that a rule(s) of European law be decoded and serve as a point of reference. In both situations, the national court - when in doubt as to the interpretation of European law - may (and - should its ruling be final and absolute - must) refer to the Court of Justice of the European Union for preliminary ruling. By the same token, should the courts be left with no doubt, they are both authorised and obliged to conduct interpretation of European company law using in its own endeavour.

The application of European company law by domestic courts entails prior interpretation of EU legislation. In addition, decoding the EU legislative model serves as a reference point in the indirect application of European company law by way of pro-European interpretation of domestic company law. Researching the manner for determining the model providing the point of reference in interpretation of European company law and pro-European interpretation of domestic company law is based on the following premises (research hypotheses):

Firstly, the manner of interpretation of European company law is affected by both the specific nature of European company law and l'acquis communautaire. The proposition of the autonomous interpretation of European law entails both a premise regarding the scope of the application of rules decoded from European acts of law (autonomy of regulation) and the manner of interpretation of such rules (uniform interpretation).

Secondly, interpretation methods are subject to the principle of uniform interpretation, which aims to safeguard uniform understanding and application of l'acquis EUwide. The principle is crystallised by way of: (i) having regard to all language versions of acts of law deemed authentic, (ii) interpreting secondary company law in line with primary sources of law, including in particular the fundamental principles of European law, (iii) interpreting rules of law with regard to their context and purpose (functional interpretation), contemporaneously bearing in mind all methods of interpretation and not ceasing the process upon having construed an unambiguous and explicit piece of legislation.

pitałowego" 2008, no. 3, p. 361; K. Oplustil, O potrzebie proeuropejskiej wyktadni polskiego prawa spótek, „Przegląd Prawa Handlowego” 2010, no. 9, p. 5. 
Thirdly, when undertaking pro-European interpretation one must (i) have regard to all domestic methods of interpretation, (ii) in line with the blanket ban on contra legem interpretation, and (iii) bear in mind the purpose and wording of a directive serving as a point of reference for pro-European interpretation, as far as possible. "As far as possible" is rightly construed as a degree of openness to the interpretation of domestic provisions having regard to the purpose of a directive.

\section{Literature}

Babusaux U., Die richtlinienkonforme Auslegung im deutschen und französischen Zivilrecht. Ein rechtsvergleichender Beitrag zur europäischen Methodendiskussion, Baden-Baden 2007.

Balddauf N., Richtlinienverstoß und Verschiebung der Contra-legem-Grenze im Privatsverbältnis, Tübingen 2013.

Conac P.-H., Director's Duties in Groups of Companies - Legalizing the Interest of the Group at the European Level, "European Company and Financial Law Review" 2013, no. 2.

Godek A., Zastosowanie derywacyjnej koncepcji wyktadni prawa do rozstrzygania spraw ze stosowaniem przepisów unijnych, "Ruch Prawniczy Ekonomiczny i Socjologiczny" 2011, vol. 1.

Hopt K.J., Europäisches Gesellschaftsrecht im Lichte des Aktionsplans der Europäischen Kommission vom Dezember 2012, "Zeitschrift für Unternehmens- und Gesellschaftsrecht" 2013, no. 2 .

Lutter M., Bayer W., Schmidt J., Europäisches Unternehmensrechts- und Kapitalmarktrecht, "Zeitschrift für Unternehmens- und Gesellschaftsrecht” 2012, Sonderheft 1.

Eętowska E., „Multicentrycznośc” polskiego systemu prawa i wyktadnia jej przyjazna, [in:] Rozprawy prawnicze. Ksiega pamiątkowa Profesora Maksymiliana Pazdana, eds. L. Ogiegło, W. Popiołek, M. Szpunar, Kraków 2002.

Mik C., Metodologia implementacji europejskiego prawa wspólnotowego w krajowych porzqdkach prawnych, [in:] Implementacja prawa integracji europejskiej w krajowych porzqdkach prawnych, ed. C. Mik, Torun 1998.

Napierała J., Uwagi na temat wyktadni prawa krajowego zgodnej z dyrektywami europejskiego prawa spótek, "Czasopismo Kwartalne Całego Prawa Handlowego, Upadłościowego oraz Rynku Kapitałowego” 2008, no. 3.

Opalski A., Europejskie prawo spótek - zasady prawa europejskiego i ich wptyw na polskie prawo spótek, Warszawa 2010.

Oplustil K., O potrzebie proeuropejskiej wyktadni polskiego prawa spótek, "Przegląd Prawa Handlowego" 2010, no. 9. 
90 | Adam Mickiewicz University Law Review

Radwański Z., Derywacyjna koncepcja wyktadni polskiego prawa prywatnego a wyktadnia prawa Unii Europejskiej, [in:] Aurea praxis aurea theoria. Ksiega pamiatkowa ku czci Profesora Tadeusza Erecińskiego, eds. J. Gudowski, K. Weitz, vol. 2, Warszawa 2011.

Radwański Z., Zieliński M., Stosowanie i wyktadnia prawa cywilnego, [in:] System prawa prywatnego, vol. 1, Prawo cywilne - częśc ogólna, ed. M. Safjan, Warszawa 2012.

Safjan M., Europeizacja prawa prywatnego - ewolucja czy rewolucja. Perspektywa orzecznicza, [in:] Aurea praxis aurea theoria. Ksiega pamiatkowa ku czci Profesora Tadeusza Erecińskiego, eds. J. Gudowski, K. Weitz, vol. 2, Warszawa 2011.

Steinke K., Die Übertragbarkeit der Keck-Rechtsprechung des EuGH auf die Niederlassungsfreiheit, Frankfurt am Main - Berlin - Bern - Bruxelles - New York - Oxford 2009. System prawa prywatnego, vol. 2, Prawo cywilne - czesśc ogólna, ed. Z. Radwański, Warszawa 2002.

Wróbel A., Znaczenie orzecznictwa "Cassis de Dijon” Trybunatu Sprawiedliwości Wspólnot Europejskich a rozwój europejskiego prawa żywnościowego, "Rejent” 1995, no. 10.

Ziembiński Z., Teoria prawa, Warszawa - Poznań 1978.

Wróblewski J., Rozumienie prawa i jego wyktadnia, Wrocław 1990.

Wentkowska A., Interpretacja in dubio pro communitate - dyrektywa wyktadni proeuropejskiej w orzecznictwie sądów polskich, [in:] Doświadczenia prawne pierwszych lat cztonkostwa Polski w Unii Europejskiej, eds. S. Biernat, S. Dudzik, Warszawa 2011.

\section{SUMMARY}

\section{A few remarks on the interpretation of European company law}

The application of European company law by domestic courts entails prior interpretation of EU legislation. Firstly, the manner of interpretation of European company law is affected by both the specific nature of European company law and l'acquis communautaire. Secondly, interpretation methods are subject to the principle of uniform interpretation, which aims to safeguard uniform understanding and application of l'acquis EUwide. Thirdly, when undertaking pro-European interpretation one must (i) have regard to all domestic methods of interpretation, (ii) in line with the blanket ban on contra legem interpretation, and (iii) bear in mind the purpose and wording of a directive serving as a point of reference for pro-European interpretation, as far as possible.

Keywords: European Union, company law

Jacek Napiera£a, Adam Mickiewicz University Poznań, Faculty of Law and Administration, Al. Niepodległości 53, 61-714 Poznań, e-mail: jacek.napierala@amu.edu.pl. 